\title{
Post-BEPS Tax Advisory and Tax Structuring from a Tax Practitioner's View
}

\author{
Paul Lankhorst \& Harmen van Dam*
}

\begin{abstract}
The international tax landscape is changing and it is changing fast. The political perception is that taxation of multinational enterprises is not aligned with the 'economic activity' that produces their profits (i.e. not aligned with 'value creation'). The perception links 'value creation' with 'employees and sales'.

In the BEPS Project of the OECD, the OECD attempts to combat base erosion and profit shifting and to align taxation with value creation. In this article, the authors discuss the impact they expect BEPS to have on tax advisory and tax planning. The focus goes to BEPS Actions 7, 8-10 and 13 .

By maintaining the separate entity approach under BEPS for the taxation of multinationals, has the OECD been forced to 'stretch' existing rules beyond their limits? Will the created uncertainty lead to a shift from 'aggressive tax planning' by multinationals to 'aggressive tax collection' by tax administrations? Will the role of tax advisory change from advising on the lowest possible effective tax rate to a broader advice including risk appetite and public expectations?
\end{abstract}

Keywords: BEPS, value creation, tax structuring, international taxation

\section{Introduction}

\subsection{Background}

The international tax landscape is changing and it is changing fast. ${ }^{1}$ In 2013, the OECD and G20 countries adopted a 15-point Action Plan to address Base Erosion and Profit Shifting (BEPS). ${ }^{2}$ On 5 October 2015, the OECD published the Final BEPS package for reform of

* Paul Lankhorst, MSc LLM, is tax adviser at Loyens \& Loeff. Harmen van Dam, LLM, is tax partner at Loyens \& Loeff.

1. See OECD, Addressing Base Erosion and Profit Shifting (2013), at 47.

2. See OECD, Action Plan on Base Erosion and Profit Shifting (2013). the international tax system to tackle tax avoidance. ${ }^{3}$ In 2014, the Fiat, Apple and Starbucks cases showed that the European Commission started to actively use state aid rules to combat tax avoidance. ${ }^{4}$ On 30 August 2016 the European Commission concluded that Ireland granted Apple tax advantages amounting to EUR 13 billion. ${ }^{5}$ There is no doubt that the changing tax landscape influences tax advisory and tax planning. In this article we discuss the impact of these changes on the role of tax planning and tax advisory already existing and for the future. By maintaining the separate entity approach under BEPS for the taxation of multinationals, has the OECD been forced to 'stretch' existing rules beyond their limits? Will the created uncertainty lead to a shift from 'aggressive tax planning' by multinationals to

3. See OECD, Explanatory Statement, OECD/G20 Base Erosion and Profit Shifting Project (2015) (hereinafter Explanatory Statement); OECD, Addressing the Tax Challenges of the Digital Economy, Action 1- 2015 Final Report (2015) (hereinafter Action 1 Report); OECD, Neutralising the Effects of Hybrid Mismatch Arrangements, Action 2 - 2015 Final Report (2015) (hereinafter Action 2 Report); OECD, Designing Effective Controlled Foreign Company Rules, Action 3 - 2015 Final Report (2015) (hereinafter Action 3 Report); OECD, Limiting Base Erosion Involving Interest Deductions and Other Financial Payments, Action 4 - 2015 Final Report (2015) (hereinafter Action 4 Report); OECD, Countering Harmful Tax Practices More Effectively, Taking into Account Transparency and Substance, Action 5 - 2015 Final Report (2015) (hereinafter Action 5 Report); OECD, Preventing the Granting of Treaty Benefits in Inappropriate Circumstances, Action 6 - 2015 Final Report (2015) (hereinafter Action 6 Report). OECD, Preventing the Artificial Avoidance of Permanent Establishment Status, Action 7 - 2015 Final Report (2015) (hereinafter Action 7 Report). OECD, Aligning Transfer Pricing Outcomes with Value Creation, Actions 8-10 - 2015 Final Reports (2015) (hereinafter Action 8-10 Reports). OECD (2015), Measuring and Monitoring BEPS, Action 11 - 2015 Final Report (2015) (hereinafter Action 11 Report); OECD, Mandatory Disclosure Rules, Action 12 - 2015 Final Report (2015) (hereinafter Action 12 Report); OECD, Transfer Pricing Documentation and Country-by-Country Reporting, Action 13 - 2015 Final Report (2015) (hereinafter Action 13 Report); OECD, Making Dispute Resolution Mechanisms More Effective, Action 14 - 2015 Final Report (2015) (hereinafter Action 14 Report); OECD, Developing a Multilateral Instrument to Modify Bilateral Tax Treaties, Action 15 - 2015 Final Report (2015) (hereinafter Action 15 Report).

4. See e.g. Commission Decision of 17 October 2014, OJ C 369 SA.38373 (hereinafter Apple Case); Commission Decision of 21 October 2015, OJ L 351 SA.38375 (hereinafter Fiat Case); Commission Decision of 6 February 2015, OJ C 44 SA.38944 (hereinafter Amazon Case); Commission Decision of 21 October 2015, OJ L 83 SA.38374 (hereinafter Starbuck (ase). For some analysis from a US perspective of these Commission initiatives, see U.S. Department of the Treasury, 'The European Commission's recent state aid investigations of transfer pricing rulings', White Paper (2016).

5. European Commission, 'State Aid: Ireland Gave Illegal Tax Benefits to Apple Worth up to $€ 13$ billion' (2016), available at <http://europa.eu/ rapid/press-release_IP-16-2923_en.htm> (last visited 20 June 2017). 
'aggressive tax collection' by tax administrations? Will the role of tax advisory change from advising on the lowest possible effective tax rate to a broader advice including risk appetite and public expectations?

\subsection{Research Question}

In this article we answer the following question:

As tax practitioners, which impact do we expect from BEPS on the role of tax structuring and tax advisory of MNEs?

The political perception is that taxation of multinational enterprises (MNEs) is not aligned with the 'economic activity' that produces their profits (i.e. not aligned with 'value creation). ${ }^{6}$ The perception links 'value creation' with 'employees, assets, and sales'. 7 BEPS Action 7 (Preventing the artificial avoidance of permanent establishment status) ${ }^{8}$ and Actions 8-10 (Aligning transfer pricing outcomes with value creation $)^{9}$ attempt to address this issue. Therefore, our focus goes to these topics. Actions $8-10$ are expected to have a big impact because they change the fundamentals underlying the arm's length principle and have direct impact without the need of further implementation. ${ }^{10}$ Although Action 7 requires implementation through tax treaties (or the multilateral instrument), ${ }^{11}$ we expect a substantial impact because it lowers the threshold of taxable presence in a country. ${ }^{12}$ In a globalising world where decision-making is not centralised in one location but spread across the globe, many MNEs will be faced with (dis-

6. See e.g., Council Directive (EU) 2016/1164 of 12 July 2016 laying down rules against tax avoidance practices that directly affect the functioning of the internal market, PB L 193, at 1; OECD, 'Multilateral Convention to Implement Tax Treaty Related Measures to Prevent Base Erosion and Profit Shifting' (2016), available at <www.oecd.org/tax/ treaties/multilateral-convention-to-implement-tax-treaty-relatedmeasures-to-prevent-BEPS.pdf> (last visited 20 June 2017), at 1. See for a comparison Y. Brauner, 'BEPS: An Interim Evaluation', 6 World Tax Journal 1, at 32 and 38 (2014). At 38: '... for transfer pricing, the OECD has (unprecedently) produced what sounds like a principle: allocation of tax base according to value creation.

7. See for the discrepancy with regard to sales, e.g. BBC, 'Starbucks Paid Just f8.6m UK Tax in 14 Years' (2012), available at <www.bbc.com/ news/business-19967397> (last visited 20 June 2017). See for the value creation with regard to employees, e.g. Action 8-10 Report (2015), above n. 3; Dutch Decree of 15 January 2011, no. IFZ2010/457M, at 5. Payroll and assets would represent the supply view of income production, and corporate sales would represent the demand view of income production. See for an analysis P.B. Musgrave, 'Principles for Dividing the State Corporate Tax Base', in: C.E. McLure Jr. (ed.), The State Corporation Income Tax: Issues in Worldwide Unitary Combination (1984), at 228-46. See for extensive analyses also M.F. de Wilde, Sharing the Pie: Taxing Multinationals in a Global Market, diss. Erasmus University Rotterdam (2015), available at <https://papers.ssrn.com/ sol3/papers.cfm?abstract_id=2564181 > (last visited 20 June 2017) (Ch. 6).

8. See Action 7 Report, above n. 3 .

9. See Action 8-10 Reports, above n. 3.

10. Many countries directly apply the OECD Guidelines.

11. On 24 October 2016, the OECD published the text of the 'Multilateral Convention to Implement Tax Treaty Related Measures to Prevent Base Erosion and Profit Shifting'. The treaty is now open for ratification.

12. See for some analysis M. de Wilde, 'Lowering the Permanent Establishment Threshold via the anti-BEPS Convention: Much Ado About Nothing?', to be published in Intertax. cussions about) the presence of permanent establishments. ${ }^{13}$ Action 13 (Transfer pricing documentation and country-by-country reporting) ${ }^{14}$ have the biggest impact on tax structuring and tax advisory will give tax administrations full insight into the transfer pricing strategies of MNEs, forcing them to have defendable tax structures and responding quickly to BEPS. We also expect that Action 6 (Preventing the granting of treaty benefits in inappropriate circumstances) ${ }^{15}$ will have a big impact, since it denies treaty benefits in many situations where such benefits are currently available. Based on our areas of expertise, we left this element open for further research. The expected consequences specifically related to Action 6 require further investigation.

To answer the research question, we first discuss the proposed measures of BEPS Actions 7, 8-10 and 13 and the consequences we expect these measures to have on tax advisory and tax structuring. We then discuss three issues of international corporate taxation that BEPS does not address.

\section{Expected consequences of BEPS}

\subsection{Introduction}

In this section we explain which consequences we expect from the outcomes of the implementation of the BEPS in the international corporation tax systems of countries. Before being able to do so, it is necessary to briefly describe the proposed measures of BEPS, which we expect to have the biggest impact. As described in Section 1.2, this concerns Actions 8-10, Action 7 and Action 13. For these Actions, we will first describe the most important observations and we will then describe the consequences we expect from these observations.

\subsection{Actions 8-10}

\subsubsection{Aligning Transfer Pricing Outcomes with Value Creation}

The arm's length principle is used by countries as the cornerstone of transfer pricing rules. ${ }^{16}$ The OECD provides guidance on the interpretation of the arm's length principle in the OECD Transfer Pricing Guidelines (OECD Guidelines). ${ }^{17}$ In its effort to combat BEPS, the OECD was of the view that the guidance on the arm's length principle needed to be clarified and strengthened. ${ }^{18}$ Actions 8-10 give the 'clarification' proposed by the

13. Ibid

14. See Action 13 Report, above n. 3

15. See Action 6 Report, above n. 3 .

16. The arm's length standard can be found in the equivalents of Art. 9 OECD Model Tax Convention in the double tax conventions of countries.

17. See OECD, OECD Transfer Pricing Guidelines for Multinational Enterprises and Tax Administrations (2010), revised in: OECD (2015) Action 8-10 Reports, above n. 3.

18. See Action 8-10 Reports, above n. 3, at 9-10. 
OECD and focuses on intangibles, risks and re-characterisation of transactions. ${ }^{19}$

\subsubsection{Most Important Observations in Relation to Actions $8-10$}

We deem the following observations to be the most important conclusions of Actions 8-10:

1. Actions 8-10 stretch the arm's length principle beyond its boundaries by putting economic concepts of what third parties should do according to economic theories above what third parties actually do;

2. Actions 8-10 imply that contracts are irrelevant, which stretches arm's length principle to the extent that it almost resembles a formulary apportionment based on functionality;

3. Actions $8-10$ use vague concepts to draw conclusions.

Below we explain where Actions 8-10 implicitly or explicitly draw these conclusions. Subsequently we will explain which consequences this has on the tax planning of MNEs.

- Ad 1. Actions 8-10 stretch the arm's length principle by putting economic concepts of what third parties should do according to economic theories above what third parties actually do

Although a more fundamental solution to tackle BEPS is in our view preferred (see Section 3), the OECD intends to maintain the arm's length principle as cornerstone for transfer pricing rules. ${ }^{20}$ Nonetheless, the OECD acknowledges that under existing interpretations of the arm's length principle, it may provide opportunities for base erosion and profit shifting. ${ }^{21}$ Actions 8-10 are presented as a clarification of how the arm's length principle should be interpreted. ${ }^{22}$ But Actions $8-10$ go further than that. As we will demonstrate below, the 'clarification' of the arm's length principle given by the OECD stretches the arm's length principle beyond its historic meaning by shifting from looking at what independent entities actually do to what independent entities should do according to economic theory.

To demonstrate this, we go back to the basics of the arm's length principle and look at the wording of Article 9(1) of the OECD Model Convention (OECD Model):

Where a) an enterprise of a Contracting State participates directly or indirectly in the management, control or capital of an enterprise of the other Contracting State, or b) the same persons participate directly or indirectly in the management, control or capital of

19. Ibid

20. See OECD, 'BEPS - Frequently Asked Questions', available at <www. oecd.org/ctp/beps-frequentlyaskedquestions.htm\#Action8?> (last visited at 20 June 2017) at no. 54.

21. See Ibid. at no. 55 and 108. See also for a short analysis of the weaknesses and strengths of the arm's length principle: O. Treidler, 'The Arm's Length Principle in the Times of BEPS' (2016), Discussion Paper, available at <DOI:10.13140/RG.2.1.1937.1286> (last visited 20 June 2017), at 3-4

22. See Action 8-10 Reports, above n. 3. The OECD's Action Reports on transfer pricing have been incorporated in the OECD's Transfer Pricing by decision of the OECD Council on 23 May 2016. an enterprise of a Contracting State and an enterprise of the other Contracting State, and in either case conditions are made or imposed between the two enterprises in their commercial or financial relations which differ from those which would be made between independent enterprises, then any profits which would, but for those conditions, have accrued to one of the enterprises, but, by reason of those conditions, have not so accrued, may be included in the profits of that enterprise and taxed accordingly. (emphasis added; HvD and PL)

It follows from the wording of Article 9(1) that a comparison should be drawn with the conditions made or imposed between independent enterprises. As such, one complies with the arm's length principle if one acts as independent enterprises also do. Actions 8-10 deviate from this basic principle of the arm's length principle. Below we give two examples.

Example 1. Requirement to demonstrate completely rational behaviour

In its guidance on re-characterisation of transactions, Actions 8-10 state that 'The transaction [...] may be disregarded $[\ldots]$ where the arrangements made in relation to the transaction, viewed in their totality, differ from those which would have been adopted by independent enterprises behaving in a commercially rational manner in comparable circumstances. ${ }^{23}$ It follows from this statement that the OECD does not simply require that related companies act in line with arrangements that would have been adopted by independent enterprises, but that it adds the criterion of commercial rationality to the arm's length principle: the OECD intends to look at what independent enterprise would do if they would act in a commercially rational manner.

What independent enterprises would do if they acted in a commercially rational manner differs from what independent enterprises actually do. Nobel Prize winner Daniel Kahneman has shown that, in reality, the assumption of rational economic decision-making is false. ${ }^{24}$ The examples given by Kahneman show that irrational decision-making is very common. A group of 200 respondents were asked the following:

Imagine that you have decided to see a play and paid the admission price of $\$ 10$ per ticket. As you enter the theatre, you discover that you have lost the ticket. Would you pay $\$ 10$ for another ticket?

$46 \%$ of the respondents answered with yes, 54\% with no. Then a group of 183 respondents were asked the following:

Imagine that you have decided to see a play and paid the admission price of $\$ 10$ per ticket. As you enter

23. See OECD (2015), above n. 17, at 39-40.

24. See D. Kahneman, 'New Challenges to the Rationality Assumption', 150, Journal of Institutional and Theoretical Economics no. 1 (1994) at 18-36. 
the theatre, you discover that you have lost a $\$ 10$ bill. Would you pay $\$ 10$ for a ticket to the play?

$88 \%$ of the respondents answered with yes, $12 \%$ with no. Although the outcome of both scenarios is identical, the respondents gave different answers. As follows from this example and many other examples given by Kahneman, human behaviour is subject to limited rationality. ${ }^{25}$ It does therefore not fit within the arm's length principle to require full rationality in intragroup transactions where third party transactions are characterised by limited rationality.

Example 2. Requirement to analyse all options realistically available

Another topic where Actions 8-10 replace actual behaviour of independent enterprises with economic concepts of what independent enterprises should do according to economic theory is the requirement to always choose the 'best option realistically available'. Actions 8-10 state that

Independent enterprises, when evaluating the terms of a potential transaction, will compare the transaction to the other options realistically available to them, and they will only enter into the transaction if they see no alternative that offers a clearly more attractive opportunity to meet their commercial objectives. ${ }^{26}$

In reality, people will more readily choose the option that is 'good enough' rather than the best option out of those available. ${ }^{27}$ Human beings make their economic decisions mainly on the basis of heuristics (rules of thumb) and not on the basis of well-considered choices between all of the options available. By requiring to choose the best option out of all options realistically available, the OECD deviates from actual human behaviour.

In conclusion, human behaviour is marked by limited rationality and opportunism. It would therefore be inappropriate to impose economic concepts on transactions between associated enterprises where (the board members of) independent enterprises do not follow these economic concepts. The arm's length principle's purpose is to allocate the right to tax the profits that an MNE actually makes and not to enable tax authorities to tax profits that an associated enterprise could have made if it behaved according to certain prescriptive economic theories. $^{28}$

27. As demonstrated by H. Simon, see e.g. G. Fellner, W. Güth \& E. Martin, 'Satisficing or Optimizing? An Experimental Study', Discussion Paper on Strategic Interaction (2006); T. Hindle, Guide to Management Ideas and Gurus (2008).

28. For more information, see M.A. de Lange, R. Hafkenscheid \& P. Lankhorst, '(Non-)Recognition of Transactions between Associated Enterprises: on Behaving in a Commercially Rational Manner, Decision-Making Traps and BEPS', 22 International Transfer Pricing Journal no. 2 (2015).
- $\quad$ Ad 2. OECD implies that contractual arrangements are irrelevant, which stretches arm's length principle to the extent that it almost resembles a formulary apportionment based on functionality

Under the arm's length principle, transactions are priced taking into account functions performed, assets owned and risks assumed. ${ }^{29}$ Actions 8-10 give an interesting interpretation of how to allocate risks and assets. With regard to risks assumed, Actions 8-10 state that risks contractually assumed by a party that cannot in fact exercise meaningful and specifically defined control over the risks, or does not have the financial capacity to assume the risks, will be allocated to the party that does exercise such control and does have the financial capacity to assume the risks. ${ }^{30}$

The OECD developed a step plan to determine to which entity it deems to assume the risks for the purpose of a transfer pricing analysis. This is not necessarily the entity that contractually incurs the risks. On the contrary, under BEPS 8-10 contractual arrangements seem to have become irrelevant. The OECD developed the following step plan to allocate risks for the purpose of a transfer pricing analysis: ${ }^{31}$

1. Identify economically significant risks with specificity;

2. Determine how the risks are contractually assumed by the enterprises under the terms of the transaction;

3. Determine through a functional analysis how the associated enterprises that are parties to the transaction operate in relation to assumption and management of the specific, economically significant risks, and in particular which enterprise or enterprises perform control functions and risk mitigation functions, which enterprise or enterprises encounter upside or downside consequences of risk outcomes, and which enterprise or enterprises have the financial capacity to assume the risk;

4. Steps 2-3 will have identified information relating to the assumption and management of risks in the controlled transaction. The next step is to interpret the information and determine whether the contractual assumption of risk is consistent with the conduct of the associated enterprises and other facts of the case by analysing (i) whether the associated enterprises follow the contractual terms [...]; and (ii) whether the party assuming risk, as analysed under (i), exercises control over the risk and has the financial capacity to assume the risk

5. Where the party assuming risk under steps 1-4(i) does not control the risk or does not have the financial capacity to assume the risk, apply the guidance on allocating risk. The guidance on allocating risk refers to functions (see below). In other words: step 3 prevails over step 2 .

29. OECD (2010), above n. 17, at 43.

30. See OECD (2010), above n. 17, at 243-46.

31. OECD (2015), above n. 17, at 22. 
6. The actual transaction as accurately delineated by considering the evidence of all the economically relevant characteristics of the transaction [...], should then be priced taking into account the financial and other consequences of risk assumption, as appropriately allocated, and appropriately compensating risk management functions.

The step plan does not explicitly state that contractual arrangements are irrelevant: Step 2 states that the contractual arrangements should be reviewed as part of the analysis. That contracts are considered irrelevant follows from the remainder of the step plan. If step 2 is not consistent with step 3, step 3 prevails. As such, step 3 always determines allocation of risk. Under step 3, there are three elements that determine risk allocation: (i) who performs and controls functions in relation to the risk, (ii) who encounters the upsides and downsides of the risk and (iii) who has the financial capability to assume the risk. The first element clearly ignores contractual arrangements. At first sight, the second and third element seem to depend on contractual arrangements. A closer look at the guidance of Actions 8-10 shows that this is only an illusion.

Hafkenscheid has demonstrated that the questions of who encounters the upsides and downsides of the risk and who has the financial capability to assume the risk, are linked to functionality in Actions $8-10 .{ }^{32}$ In summary, this follows from paragraphs 1.85 and 1.103 of Actions 8-10. Paragraph 1.85 together with 1.103 concludes that a company (Company A) that is the legal owner of an asset, but does lack capability to decide on whether to invest in the particular asset, and whether and how to protect its investment including whether to dispose of the asset, is only entitled to a risk-free return on its investment:

Company A does not have control over the economically significant risks associated with the investment in and exploitation of the asset, and those risks should be aligned with control of those risks by Companies B and $\mathrm{C}$. The functional contribution of Company $\mathrm{A}$ is limited to providing financing for an amount equating to the cost of the asset that enables the asset to be created and exploited by Companies B and C. However, the functional analysis also provides evidence that Company A has no capability and authority to control the risk of investing in a financial asset. Company A does not have the capability to make decisions to take on or decline the financing opportunity, or the capability to make decisions on whether and how to respond to the risks associated with the financing opportunity. Company A does not perform functions to evaluate the financing opportunity, does not consider the appropriate risk premium and other issues to determine the appropriate pricing of the financing opportunity, and does not evaluate the appropriate protection of its financial investment. [...] Company A would not be entitled to any more than a risk-free return as an appropriate measure of the profits it is entitled to retain, since it lacks the capability to control the risk associated with investing in a riskier financial asset. The risk will be allocated to the enterprise which has control and the financial capacity to assume the risk associated with the financial asset.

The OECD uses a similar reasoning with regard to ownership of intangible assets. Paragraph 6.35 of the OECD's Transfer Pricing Guidelines states that legal rights and contractual arrangements form the starting point for any transfer pricing analysis involving intangibles. ${ }^{33}$ One would again expect that this means that contractual arrangements are considered relevant. However, Actions 8-10 continue by stating that 'while determining legal ownership and contractual arrangements is an important first step in the analysis, these determinations are separate and distinct from the question of remuneration under the arm's length principle'. ${ }^{34}$ The contractual right to exploit an intangible does not - according to the OECD - give any right to retain returns on the intangible. The legal owner of intangibles is only entitled to all returns derived from the exploitation of the intangibles, if it performs all the functions related to the development, enhancement, maintenance, protection and exploitation (DEMPE) of the intangibles. ${ }^{35}$ If the legal owner neither controls nor performs these so-called DEMPE functions, the legal owner would not be entitled to any ongoing benefit attributable to the outsourced functions. The OECD ignores that in third party transactions, the owner of an asset is often entitled to the returns on that asset, even without having the aforementioned capabilities. In third party transactions, the return depends on the scarcity of the asset.

As an example, one can think of the owner of capital that hires an asset manager to invest its capital. The asset manager has the capability to decide on whether to invest in a particular asset, and whether to dispose of the asset. Would the owner of the asset be merely entitled to a risk free return on its capital, while the asset manager retains all remaining results?

Another example concerns the image rights of famous football players. One would not expect the football player to perform the functions related to the exploitation of the rights itself, but to hire an agent to perform these functions on a commission basis.

From the observations above, it can be concluded that under BEPS Actions 8-10, a functional analysis taking into account functions performed, assets used and risks assumed still forms the basis of a transfer pricing analysis. However, the assumption of risks and the ownership of assets follows the functions performed in relation to the risks and assets. As a consequence, with Actions 8-10 the OECD reduced the traditional functional anal- 
ysis from an analysis of functions, assets and risks, to merely an analysis of functions.

By focusing the functional analysis only on functions performed, the OECD does not follow economic principles of how profits are divided between factors contributing to the profit. Economics is the study of how people choose to allocate their scarce resources. ${ }^{36}$ It is therefore remarkable that the OECD guidance does not take into account the scarcity of the various factors contributing to profit when stating that most emphasis is to be put on functions. Actions 8-10 ignore the basic principles of economics by only allocating value to functions instead of looking at the scarcity of all production factors (see also Section 3.1). ${ }^{37}$

All in all, while pretending to maintain the arm's length principle as leading principle for transfer pricing, the OECD stretches the interpretation of the arm's length principle to the extent that it almost resembles a formulary apportionment based on functionality.

That the OECD implies that contracts are irrelevant in a functional analysis, does not mean that the importance of concluding intercompany agreements decreases. On the contrary, as we will explain in Section 2.2.3, concluding intercompany agreements has become even more important than before.

- Ad 3. The OECD uses vague concepts to draw conclusions

Examples of vague concepts

Actions 8-10 use vague concepts to explain how in the view of the OECD the arm's length principle should be interpreted.

An important example is the primacy of the 'actual conduct' of the parties in a transaction over the contractual relationship as proposed in paragraph $1.88 .{ }^{38}$ In practice, the actual conduct of people deviates substantially from what they should be doing based on, for example, job descriptions and management reporting lines. In practice, whom of the employees in an MNE makes the actual decisions is driven by various circumstances, such as personal impact or the informal power of a staff member, which person of the staff has invented an idea, who has the capacity, capability, energy and spirit to put that idea into practice. The result thereof is that taking the 'actual conduct' of parties as starting point (i) makes it practically impossible to draw conclusions on who is doing what as this differs all the time, and (ii) potentially leads to random outcomes and thus windfall profit allocations. In many situations it will be impossible to 'trace' all steps in the invention of a successful idea, let alone how the decisions about implementing an idea are actually made. To avoid the impracticalities of looking at actual conduct of people, people invented the use of contracts as a means of establishing relations between parties. Deviating from such contractual relations and requiring that profit be allocated based on actual conduct creates uncertainty and the risk of diverging conclusions on what the 'actual conduct' of parties has been.

Another example is the guidance that is given regarding synergy benefits. Actions $8-10$ state that if important group synergies exist and can be attributed to deliberate concerted group actions, the benefits of such synergies should generally be shared by members of the group in proportion to their contribution to the creation of the synergy.' (emphasis added) ${ }^{39}$ The notion of 'deliberate concerted group actions' is sufficiently vague to create discussions on whether a certain synergy benefit is caused by such deliberate concerted group action. For example, are synergy benefits derived from centralising production in one plant deliberate concerted group actions? The benefit that a group member obtains by being able to borrow at more favourable conditions by reason of having a credit rating that is higher than it would be if it was unaffiliated, is apparently not considered to be attributable to deliberate concerted actions: following the OECD Guidelines such a benefit is allocated to the group member attracting the financing and is not shared between the members of the group contributing to the higher credit rating. ${ }^{40}$ But also in cases whether it is clear that there have been deliberate concerted group actions, Actions 8-10 only indicate that the synergies created by this actions should 'generally be shared among members of the group'. This implies that there are exceptions to the main rule. Our personal experience as tax practitioners is that the extraordinary cases are the main source of discussions with tax authorities, but no guidance is provided in Actions 8-10 on cases that deviate from what 'generally' happens.

\section{Deviating interpretation by different countries}

The goals that different OECD countries want to realise with BEPS are not aligned. Especially the goals of the US and the European Union seem to deviate. In an interview with BNA, the US Deputy Assistant Treasury Secretary for International Tax Policy Robert Stack indicates that some countries were concerned that the rules on risk, capital and control were previously not clear, and therefore felt the need to re-characterise transactions, but that the US managed to establish that the rules on re-characterisation have not materially changed. Mr Stack indicates that it is still the intention of the US that contracts are respected: 'we spend a lot of time trying to build up the notion that if there is a contract and tax authorities are able to see that parties act in accordance with the contract, they respect the real deal'. ${ }^{41}$ This differs from the conclusion that Actions 8-10 intend to focus on functions, not on contracts.
36. M.L. Katz and H.S. Rosen, Microeconomics (1998), at 2.

37. In addition to looking at this 'supply side' of profit generation, the demand side (revenue) should be considered. See for a comparison Musgrave, above n. 7, at 228-46.

38. OECD (2015), above n. 17, at 31-2.
39. Ibid., at 48 .

40. OECD (2010), above n. 17, at 7.13.

41. Bloomberg BNA, 'Robert Stack Discusses U.S. Participation in International Tax Fora and U.S. Tax Reform', available at <https://www.bna. com/robert-stack-deputy-m17179936316/> (last visited 25 June 2017). 
Interpretation differences with non-OECD countries will remain in place. ${ }^{42}$ An important example is the application of the arm's length principle to 'location benefits'. Non-OECD countries such as China (even though participating in BEPS) are known to have deviating views on location benefits from most OECD countries. ${ }^{43}$ China applies a broad concept of location benefits, which includes for example the general preference of Chinese consumers for foreign automotive brands. ${ }^{44}$ China may take the position that the additional sales realised as a result of this preference are taxable in China, while OECD countries may claim that these additional profits originate from the ownership of the brand name. ${ }^{45}$ While the OECD countries in this example focus at the 'supply side' of profit generation, China focusses more on the demand side (revenue). ${ }^{46}$

\subsubsection{Consequences}

We expect that stretching the arm's length principle, ignoring contracts and using vague concepts has consequences for (i) tax structuring, and (ii) tax advisory.

- $\quad$ Ad (i) Tax structuring

More disputes with tax authorities

Provoked by the ambiguous guidance on how associated enterprises should price their transactions in order to comply with the arm's length principle and feeling supported by public opinion, some tax authorities will be tempted to argue that more profits should be allocated to them. ${ }^{47}$ Not being able to enforce or rely on unambiguous and consistent guidance, and keeping in mind the deviation of the OECD Guidelines from actual behaviour of independent enterprises, many uncertainties will arise for MNEs.

\section{Shift of functions away from high-tax countries}

We expect that MNEs will be reluctant to allocate large profits to empty cash boxes (including IP companies), knowing that they will be confronted with disputes with tax authorities feeling supported by the OECD guidance. Refrained from using empty cash boxes, MNEs would be tempted to - notwithstanding the lack of business needs - centralise functions (potentially to tax friendly locations) to reduce the uncertainty of how different countries will interpret the arm's length principle. As discussed in Section 3.2, corporation tax is already considered to be among the most distorting taxes. Triggering MNEs to 'artificially' centralise functions

42. There are several differences between the approach of the United Nations and the OECD, see United Nations, Practical Manual on Transfer Pricing for Developing Countries (2013), chapter 10; OECD (2015), above n. 3.

43. See United Nations, above n. 42, at 376-79, 387-88

44. Ibid., at 377

45. M.A. de Lange and P.W.H. Lankhorst, 'The Impact of Location Advantages on the Transfer Pricing of Multinationals: On the Chinese Love for European Designer Handbags and Lower Production Costs in India', 21 International Transfer Pricing Journal 4 (2014).

46. See Musgrave, above n. 7

47. See for a comparison in view of PE profit attribution in response to the lowering of PE thresholds with a view to Action 7; De Wilde, above n. 12 , at Sec. 4.3 in tax friendly locations might hamper business and trigger relocation of jobs, harming the economy.

\section{Reduced value of the OECD Guidelines}

The interpretation of Actions 8-10 deviates from economic reality and uses vague concepts such as 'actual conduct'. Stretching the arm's length principle beyond its limits in this way diminishes the value the OECD guidelines traditionally have had in the practical application of the arm's length principle. Tax courts in various jurisdictions will perceive the ambiguous guidance that does not conform to economic reality as a less reliable source of information for resolving tax disputes. This effect is strengthened by the limited democratic foundation of the OECD Guidelines. In many countries, the OECD Guidelines are merely recommendations of an intergovernmental organisation. ${ }^{48}$

\section{New tax planning opportunities}

The diminishing authority will lead to differences in interpretation and application of the arm's length principle between jurisdictions, leading to more instead of less opportunities to exploit differences between countries. Tax courts in some countries may fully apply the new OECD Guidance, while tax courts in other countries may maintain a more strict interpretation of the arm's length principle. This inevitably creates disparities in the interpretation of the arm's length principle, causing undesirable tax planning opportunities for MNEs.

Different goals and interpretations by different countries create mismatches in the interpretation of the arm's length principle. New tax planning opportunities arise on which no common knowledge has yet been developed.

\section{- $\quad$ Ad (ii) Tax advisory}

\section{Advice more intragroup agreements}

The more opportunistic behaviour of tax authorities will lead to more disputes between MNEs and tax authorities. In addition, not being able to rely on unambiguous and consistent guidance will force MNEs to thoroughly document the reasons for all their transactions and the arguments why the price of the transaction is arm's length to be prepared for potential discussions. Although in the reasoning of Actions 8-10 contracts are irrelevant for the determination of an arm's length remuneration, MNEs will be impelled to conclude intragroup contracts to formally document and leave no doubt about the roles and responsibilities of each party in a transaction. This will be helpful in defending the roles and responsibilities of the parties in court against claims that the roles and responsibilities were different based on actual conduct.

Broader advisory role towards taxpayers

Our personal expectation as tax practitioners is that tax advisers will be more involved in advising clients on

48. See also R. Luja, 'Fiscale rulings en staatssteun', Nederlands Juristenblad 14 (2015), at 870. 
conscious decision-making and awareness when it comes to tax planning. We refer to Section 3.3 for guidance on creating awareness of MNEs attitude towards tax planning.

More critical role towards positions taken by tax author$\underline{\text { ities }}$

As stated above, some tax authorities will be tempted to argue that more profits should be allocated to them provoked by the ambiguous guidance on how associated enterprises should price their transactions. In our personal observations as tax practitioners, the new OECD guidance has already been accepted by some advisers as the only correct interpretation of the arm's length principle. In our view, it is the role of the tax adviser to critically analyse the positions taken by tax authorities and not simply accept positions taken by tax authorities (also ex ante) as the 'truth'.

\subsection{BEPS Action 7}

\subsubsection{Lowering the Threshold for Taxable Presence}

Under Article 7 of the OECD Model Convention, business profits of foreign enterprises are only taxable in a country if the foreign enterprise has a PE in that country to which the profit is attributable. Article 5 of the OECD Model Convention contains a definition of permanent establishment. Action 7 attempts to prevent the artificial avoidance of permanent establishments by changing this definition in the Model Convention.

Currently, Article 5(5) OECD Model Convention states that where a person habitually uses the authority in a contracting state to conclude contracts in the name of a foreign enterprise, that foreign enterprise shall be deemed to have a PE in that state. As such, Article 5(5) depends on the formal conclusion of contracts in the name of the foreign enterprise. By arranging that the commissionaire does not have such an authority, the foreign enterprise can avoid having taxable presence in the other country.

Action 7 proposes to change the definition of permanent establishment in three areas: commissionaire arrangement, the exception for auxiliary activities and splitting up contracts to avoid PE status. ${ }^{49} \mathrm{We}$ expect most impact from the proposals regarding commissionaire arrangements. Action 7 proposes to lower the threshold of a permanent establishment by extending the definition of the deemed permanent establishment to persons habitually concluding contracts that are to be performed by the enterprise, or habitually playing the principal role leading to the conclusion of such contracts which are routinely concluded without material modification by the enterprise.

The OECD notes that common tax avoidance strategies use commissionaire arrangements to shift profits out of the country where the sales take place, without a substantive change in the functions performed in that country (but with a change of risks reducing the arm's length remuneration). In line with Actions $8-10,50$ Action 7 thus attempts to align profit allocation with value creation (whereby value creation is interpreted as people functions). ${ }^{51}$ Unlike Actions 8-10, Action 7 does not ignore contractual allocation of risk, but creates taxable presence of the entity that contractually assumes the risk in the country where the sales are made. ${ }^{52}$

Based on Action 7 a PE will be deemed to exist where an agent plays an important role in the conclusion of contracts between the principal and the customers.

\subsubsection{Most Important Observations in Relation to Action 7}

If and when implemented, MNEs using commissionaire arrangements may be confronted with PEs of their principal company in the commissionaire states. Although Action 7 uses commissionaire arrangements as a primary example, we expect that it will have a broader impact than only commissionaire structures. In each situation where decisions that bind legal entities, or decisions that play an important role in binding legal entities, are made outside of the country of residence of a legal entity, the extended PE definition may trigger discussions about the presence of a PE.

Decisions that bind legal entities, or decisions that play an important role in binding legal entities, were historically often made by the local management of the respective legal entity. For efficiency reasons, there is trend that not all relevant capabilities to make business decisions are present in each separate affiliate (see Section 3.1). Instead, legal entities will use capabilities available elsewhere in the group to assist in decision-making. This process is facilitated by a globalising world that offers flexibility in where people perform their functions. As a result, we more and more see that involvement in decision-making that binds a legal entity is spread across various countries. Having decision-making taking place in various countries leads to an increased risk of discussions on the presence of PEs, an increased risk of discussions on the attribution of profits to permanent establishments, and the potential obligation to file (multiple) tax returns in the PE countries.

\subsubsection{Consequences}

- Tax structuring

In our practice we observe that Action 7 is creating substantial uncertainties for MNEs. We see a trend that being 'in control' is becoming more important for MNEs. Certainty is often considered more important than low taxation. The question arises how MNEs will manage the uncertainties created by Action 7 .

Centralised decision-making in the country where a legal entity is located would decrease the risk created by Action 7. However, this would not be in line with the

50. See Action 8-10 Reports, above n. 3 .

51. See OECD, 'Revised discussion draft. BEPS Action 7: Preventing the Artificial Avoidance of PE Status' (2015), available at <www.oecd.org/ ctp/treaties/revised-discussion-draft-beps-action-7-pe-status.pdf> (last visited at 20 June 2017), at 37.

52. See De Wilde, above n. 12, at Sec. 4.3 


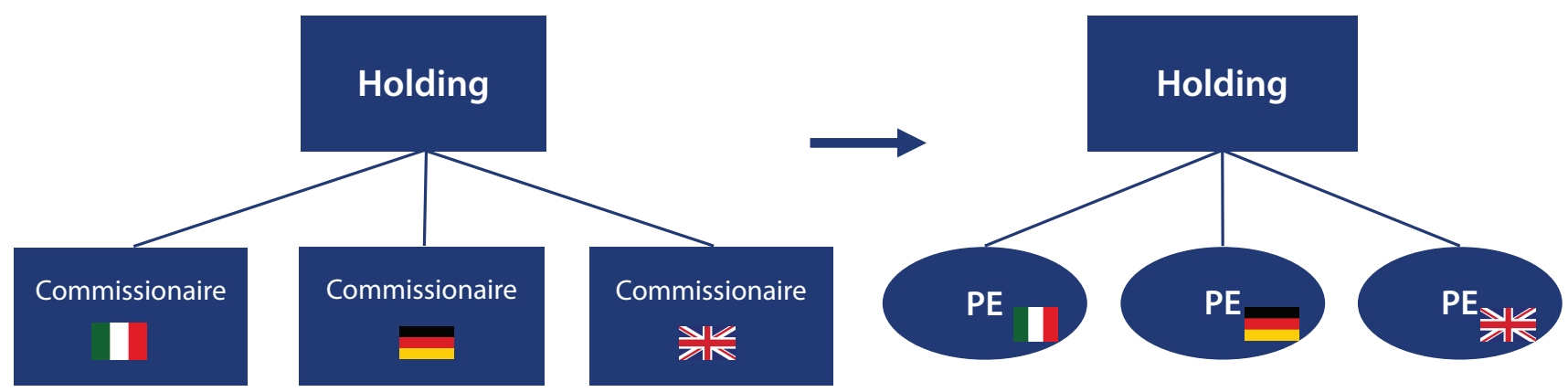

business-driven development of having relevant capabilities for decision-making spread across various locations. Another more likely scenario is that MNEs will avoid discussions with tax authorities by proactively claiming taxable presence in a country. We expect that MNEs will prefer to work with one legal entity with permanent establishments in each country where it formerly operated through a legal entity. This reduces discussions about the presence of PEs of various legal entities, and reduces the taxable presence in each country to one legal entity. As tax practitioners, we also see MNEs considering filing 'zero profit PE filings' in various countries to reduce the risk of fines.

This effect is strengthened when combined with Actions 8-10. Historically, a benefit of using a legal entity instead of a permanent establishment was that for the allocation of profits to a legal entity, the functional analysis takes into account functions performed, assets used and risks assumed. This allows MNEs to influence profit allocation through (contractual) allocation of assets and risks. For the profit allocation to PEs, the OECD states that there is no single part of the enterprise that legally owns assets and assumes risk. ${ }^{53}$ As a solution, assets and risks are allocated to that part of the enterprise that performs the significant people functions related to the asset/risk. ${ }^{54}$ As explained in Section 2.2.1, Actions 8-10 claim that also for legal entities, contractual relationships should be considered in view of functions performed. The difference between profit allocation to legal entities and that to PEs has therefore - at least according to the OECD - substantially been reduced. This contributes to the expected tendency of moving towards PE structures.

\section{- Tax advisory}

For tax advisers we expect an important role in assisting MNEs to be in control. In our observations as tax practitioners, to be in control in an uncertain tax environment does not necessarily require certainty on all tax positions taken, but does require full insight and transparent communication about the risks involved for the

53. OECD, Report on the attribution of profits to permanent establishments (2010), available at <www.oecd.org/ctp/transfer-pricing/ 45689524.pdf> (last visited 20 June 2017), at 14.

54. Lacking agreements between a head office and a PE, only functions remain. We would like to note that this may not be true for entities with legal personality that qualify as a PE because they are treated as transparent entities for tax purposes. positions taken and the alternatives, and documented reasons for accepting the risks. We refer to Section 3.3 for guidance on creating awareness of MNEs' attitude towards tax planning.

\subsection{BEPS Action 13}

\subsubsection{Nem Documentation Requirements}

Another part of the BEPS Action Plan we expect to have a big impact is Action $13 .{ }^{55}$ Action 13 contains a revised Chapter V of the OECD Guidelines dealing with transfer pricing documentation. ${ }^{56}$ The revised guidance requires MNEs to provide tax authorities with high-level information regarding their global business operations and transfer pricing policies in a Master File. In addition, it requires that detailed transactional transfer pricing documentation is provided in a Local File specific to each country, identifying material-related party transactions, the amounts involved in those transactions and the company's analysis of the transfer pricing determinations they have made with regard to those transactions. Very large MNEs are further required to file a Country-by-Country Report that will provide for each tax jurisdiction in which they do business the amount of revenue, profit before income tax, income tax paid and accrued, number of employees, stated capital, retained earnings and tangible assets. ${ }^{57}$

The OECD distinguishes three objectives of the new transfer pricing documentation: $:^{58}$

1. To ensure taxpayers give appropriate consideration to transfer pricing requirements.

2. To provide tax administrations with the information needed to conduct a transfer pricing assessment.

3. To provide tax administrations with useful information to employ in conducting an audit of the transfer pricing practices of taxpayers.

These objectives form a logical part of the OECDs efforts to combat BEPS. Tax authorities need information on the transfer pricing system of an MNE to identi-

55. See Action 13 Report, above n. 3. Within the EU the outcomes of Action 13 have been implemented on an EU wide basis by means of amending the Administrative Cooperation Directive; see Council Directive (EU) 2016/881 of 25 May 2016 amending Directive 2011/16/EU as regards mandatory, automatic exchange of information in the field of taxation, OJ L 146.

56. See Action 13 Report, above n. 3, at 11-69.

57. See Action 13 Report, above n. 3, at 9.

58. Ibid., at 12-4 
fy where the MNE may have an incentive to optimise the transfer prices used. ${ }^{59}$

\subsubsection{Most Important Observations in Relation to Action 13}

Action 13 puts a substantial administrative burden on MNEs. ${ }^{60}$ In our view, the information that needs to be included in the Master File and Country-by-Country report is in principle available within each MNE. ${ }^{61}$ For example, the Master File should include a description of the MNE's important drivers of business profits, the supply chain of the five largest products by turnover and how the MNE is financed. ${ }^{62}$ The same applies to the Country-by-Country report, which requires mainly financial input such as revenues, income tax paid and stated capital. To accommodate the complaints of MNEs, the documentation obligations have built in a certain flexibility for taxpayers to choose which information will be included in the documentation. For example, the Country-by-Country report can be based on data from consolidation reporting packages, statutory financial statements, regulatory financial statements or internal management accounts, as long as the choice is made consistently. The guidance on the Master File states that taxpayers should use prudent business judgement in determining the appropriate level of detail for the information supplied, which also gives certain freedom to MNEs.

Although the OECD made some efforts to reduce the administrative burden for MNEs,${ }^{63}$ the administrative burden could in our view have been reduced more by better guidance.

\section{- FTEs}

In the Country-by-Country report, there are ambiguous terms that make the completion of the report difficult. There are also requirements to include information that is not available. For example, an MNE should report the total number of employees on a full-time basis. There are MNEs whose accounting software only show the total number of employees, not the full-time equivalent. FTE is equal to (a) the number of total scheduled person hours divided by (b) the number of hours per week of a full-time employee. The number of hours per week of a full-time employee differs between countries (e.g. India 48 hours, the Netherlands 40 hours). No further guidance is provided on how to interpret the term FTE.

\section{- Joint Ventures}

More practical problems arise where the taxpayer is a joint venture that is included in the consolidation of one

59. Ibid., at 12

60. See e.g. A.M. Parker, 'BEPS 'Master File' Requirements Raising Concern' (2016), available at <www.bna.com/beps-master-file-m57982059 329/> (last visited 20 June 2016).

61. This might be different for the Local File where a benchmark seems to be required for each material controlled transaction.

62. See Action 13 Report, above n. 3, at 25.

63. Ibid., at 38 for an example. of the joint venture partners. ${ }^{64}$ Action 13 would in such case require that the joint venture company keeps a copy of the Master File in its administration, even though it may contain classified information that the joint venture partner may not avail of.

- Interpretation of the term 'products'

Another example is that the Master File should contain a description of the supply chain for the MNE's five largest products or service offerings. ${ }^{65}$ There is no explanation as to what the word 'product' means. A simple example. Are the iPhone 6 and the iPhone 7 different products? Is an iPhone 7 with 128GB a different product that the one with $256 \mathrm{~GB}$ ? The guidance gives MNEs the right to use prudent business judgement in determining the appropriate level of detail for the information supplied, which gives some flexibility. Nonetheless, MNEs may be faced with different requirements in different countries. Where certain countries may only accept the Master File if choice A is made, other countries may only accept choice B.

\subsubsection{Consequences}

(i) Tax structuring

Contribution to identify tax avoidance and aggressive tax planning

We expect that the documentation requirements of Action 13 will form a large contribution to the ability of tax authorities to identify tax avoidance and aggressive tax planning. With more insight into tax structures, tax authorities will be able to more efficiently identify and challenge abuse.

From the Country-by-Country report, tax authorities will be able to gain insight into the division of profits between countries, the taxation of these profits and the ratios that they deem relevant to assess the justification of the division of profits (see graph on next page).

With the Master File and Local File to complement the Country-by-Country data, tax authorities will be able to quickly verify whether the local entities of the MNE entered into transactions with the 'suspicious' jurisdictions.

Conformism: More pressure to act in accordance with 'expectations' of tax authorities ${ }^{66}$

With the knowledge that tax administrations worldwide will have an insight into the division and taxation of profits within the MNE, we believe MNEs will be encouraged to more than ever ensure that its tax structures are in line not only with all applicable tax legislation, but also with the expectations of the tax authorities. In addition, MNEs are encouraged to have transfer pricing documentation available that not only meets the

\footnotetext{
64. See also OECD, 'Public comments received Volume III. Discussion Draft on Transfer Pricing Documentation and CbC Reporting' (2014), available at <www.oecd.org/ctp/transfer-pricing/volume3.pdf> (last visited at 20 June 2017), at 16 .

65. See Action 13 Report, above n. 3, at Annex I.

66. See also para. 3.3
} 


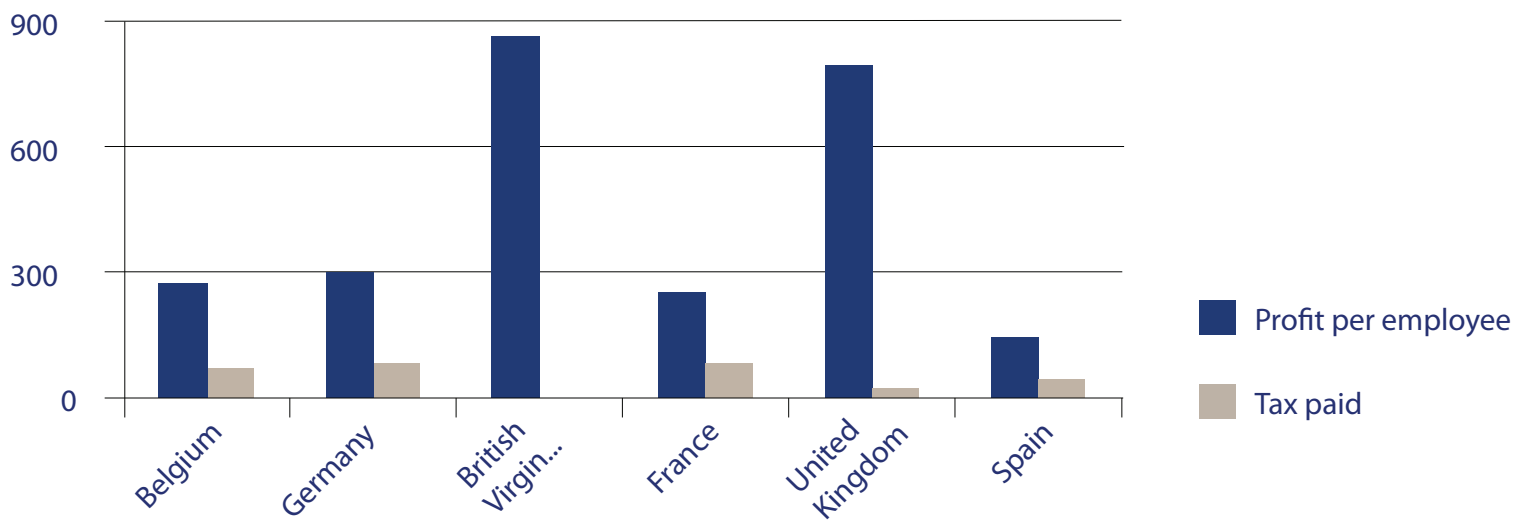

bare minimum legal requirements, but that also answers questions that tax authorities are expected to have when reviewing the documentation.

Another potential benefit of the increased transparency is that not only MNEs will be encouraged to improve their behaviour, also jurisdictions themselves may change their policy. Countries often coming up as a 'suspicious' jurisdiction in Country-by-Country reports may - under peer pressure - decide to change legislation to give a better picture in Country-by-Country reports. ${ }^{67}$

Conformism: Pressure to work with 'standard' struc$\underline{\text { tures }}$

In our experience as tax practitioners, tax authorities are more likely to challenge tax structures that are not set up in accordance with 'standard market practice'. A transfer pricing system that does not fit within the picture of how transfer pricing systems generally work risks being subject to questions of tax authorities. Many MNEs set up a transfer pricing system with one central entrepreneur, while the other entities perform 'routine' activities (e.g. contract manufacturers and limited risk distributors). MNEs who do not fit within this 'template', for example MNEs who give a high level of independence to local entities, are more likely to be subject to questions of tax authorities when presented with their transfer pricing documentation. ${ }^{68}$

67. The OECD blacklist lists non-cooperative jurisdictions, and most jurisdictions on the black list have formally enacted regulatory measures. See for an analysis on the effectiveness of the blacklist D. Masciandaro, 'Combating Black Money: Money Laundering and Terrorism Finance, International Cooperation and the G8 Role' (2004), Economics Working paper No. 56/26, available at <http://dx.doi.org/10.2139/ssrn. 561183> (last visited 20 June 2017), at 3. In addition, the EU Council agreed on the establishment of an EU list of third country non-cooperative jurisdictions and to explore coordinated defensive measures at EU level.

68. See e.g. European Commission, above n. 6. In this press release the following was said, which can lead to arbitrary taxation: 'In fact, the tax treatment in Ireland enabled Apple to avoid taxation on almost all profits generated by sales of Apple products in the entire EU Single Market. This is due to Apple's decision to record all sales in Ireland rather than in the countries where the products were sold. This structure is however outside the remit of EU state aid control. If other countries were to require Apple to pay more tax on profits of the two companies over the same period under their national taxation rules, this would reduce the amount to be recovered by Ireland.' (ii) Tax advisory

$\underline{\text { Substantial administrative burden and more compliance }}$ work

The expected preference of MNEs to have thorough transfer pricing documentation combined with the fact that the legal requirements are far from clear, puts a substantial administrative burden on MNEs and forces them to either set up internal specialised transfer pricing documentation teams or to hire specialised tax advisors to assist in preparing the transfer pricing documentation, meaning more compliance work for tax advisers, and red tape for MNEs.

\section{Accepting 'incorrect' audit adjustments}

In our observations as tax practitioners, currently many companies accept 'incorrect' audit adjustments as the risks and costs of challenging the adjustments through litigation and/or mutual agreement or arbitration proceedings simply are too high. ${ }^{69}$ These companies often don't seek a corresponding adjustment in other countries to avoid endangering the consistent application of a transfer pricing system. If all information is shared between tax authorities, audit adjustments that deviate from the transfer pricing system consistently applied by an MNE might reduce the chances of 'smooth' dispute resolution in other countries.

\section{Three Issues the Anti-BEPS Measures Don't Address}

\subsection{The Fundamental Problem of the Current Corporate Taxation System}

Apple's effective tax rate on the profits realised by its Irish subsidiary Apple Sales International was allegedly $1 \%$ in 2003 and $0.005 \%$ in $2014 .^{70}$ In the UK, Google paid 'just' $f 6 \mathrm{~m}$ tax in 2011 on a turnover of $£ 395 \mathrm{~m}^{71}$

69. See e.g. Proposal for a Council Directive of 23 May 2017 on Tax Dispute Resolution Mechanisms in the European Union, 9420/17. However, these procedures can still take several years.

70. European Commission, above n. 6 .

71. BBC, 'Google, Amazon, Starbucks: The Rise of Tax Shaming' (2013), available at <www.bbc.com/news/magazine-20560359> (last visited at 20 June 2017). 
For the public, these numbers at the least raise the question how effective the corporation tax system (in Europe) is. Politicians perceive it as easy to - within one MNE - shift profits to low-tax jurisdictions - either by transferring 'real activities' (i.e. functions) or merely ownership of assets and risks - and/or to 'erode' the tax base with deductible royalty or interest payments. ${ }^{72}$

The question arises is whether the BEPS measures are the best way to improve fairness in international taxation. Instead of implementing the BEPS measures, De Wilde, for instance, advocates a more fundamental reconsideration of the sustainability of the tax system as a whole. ${ }^{73}$ In his recent thesis on the existing model of international corporate taxation, he states:

The current model of corporate taxation finds its origins in the 1920s. It well suited the economic realities of the early days of international trade and commerce; the times when international business primarily revolved around bulk trade and bricks-and-mortar industries. But those days are long gone. Globalisation, European integration, the rise of multinational enterprises, e-commerce, and intangible assets have changed the world considerably.

These developments have caused the model to operate inconsistently with the economic reality of today. Corporate taxation and economic reality are no longer aligned. The model is ill-suited to current market realities. As a result multinational business decisions are distorted by tax considerations. The arbitrage may work to the benefit or detriment of nationally and internationally active firms. It also seems to put pressure on nation state corporate tax revenue levels. This may lead to spill-over effects and welfare losses at the end of the day. Matters seem to worsen in today's increasingly globalizing economy. ${ }^{74}$

...corporate entities are typically subject to corporation tax on an individual basis under the separate entity approach. This approach is generally upheld in the event that these taxable entities belong to an integrated group. However, in reality multinational groups of companies do not operate in a segregated manner. They operate in concert as a functionally integrated economic entity with a common objective of profit-optimisation. ${ }^{75}$

The core problem is that Actions 8-10 maintain the separate entity approach, in which each entity of an MNE

72. See e.g. C.E. McLure, Jr., 'The State Corporate Income Tax: Lambs in Wolves' Clothing', in H.J. Aaron et al. (eds.), The Economics of Taxation (1980) at 327.

73. Alternative systems have been advocated by many and proposals range from formulary systems to destination based cash flow taxation systems. See for overviews and assessments De Wilde (2015), above n. 12, at Chapters 5 and 6 .

74. See De Wilde (2015), above n. 12, at Preface.

75. Ibid., at Sec. 1.1.4.3. is taxed separately, instead of taxing the MNE as a whole. $^{76}$

Historically, each legal entity in an MNE generally had local capabilities for decision-making relevant for that entity. We see a development of having relevant capabilities for decision-making spread across various locations. For efficiency reasons, there is trend that not all relevant capabilities to make business decisions are present in each separate affiliate. Instead, legal entities use capabilities available elsewhere in the group to assist in decision-making. ${ }^{77}$ This process is facilitated by a globalising world that offers flexibility in where people perform their functions (e.g. videoconference, the cloud, regular traveling, etc.). For example sales entities don't need local experts anymore for functions other than sales (like accounting, corporate governance, finance, etc.). These functions are performed at one or more other locations. As another example, it is often difficult to find qualified people to form the board. In addition, the 'responsible people' for a specific task within an MNE change rapidly, often also to different countries. The highest ranked European marketing manager might be located in a different country than his predecessor. As a result, we more and more see that involvement in decision-making that binds a legal entity is spread across various countries.

We see that an MNE is often artificially dividend into individual entities to meet local law requirements. Therefore, taxing legal entities instead of MNEs does no longer fit within current business reality.

Actions 8-10 do not address the fundamental problems underlying the tax system, but instead try to 'fix' alleged abuses that are caused by the system, by proposing 'solutions' that still don't fit within the reality of the current international business practice.

"Basically all tax jurisdictions attempt to geographically localise business activities and the business income produced. The purpose is to ensure that business income generated mithin the territory of the taxing state is taxed by that state." 78 As noted above, the political perception is that taxation of multinational enterprises is not aligned with the economic activity that produces their profits (i.e. not aligned with 'value creation'). The perception is that value creation is for the main part attributable to sales and to employees. Actions $8-10$ and Action 7 try to address this issue. ${ }^{79}$ Actions $8-10$ seem to claim that under the arm's length principle, functions (i.e. employees) determine where profits should be allocated. Action 7 tries to align taxation with sales by creating taxable presence of foreign legal entities in the country where the sales (or other decisions) are made.

76. See for a comparison M. Kobetsky, 'The Case for Unitary Taxation of International Enterprises', 62 Bulletin for International Taxation 201 (2008). Kobetsky argues essentially that taxing highly integrated international enterprises (e.g. banks) on a unitary basis is appropriate because these businesses operate on a unitary basis.

77. See for a comparison K. Sadiq, 'Unitary Taxation: The Case for Global Formulary Apportionment', 55 Bulletin for International Taxation no. 7 (2001), at 275-86.

78. De Wilde (2015), above n. 12, at 164.

79. See Action Report 7, above n. 3, and Action Reports 8-10, above n. 3. 
But value creation is not necessarily attributable to sales and employees. Empirical research even shows that labour should play little if any role in allocating taxing rights; any causality link between labour costs and profit-making seems absent. ${ }^{80}$ Identifying where value is generated is a fundamental problem of conventional corporation taxes in an international setting. ${ }^{81}$ Value creation is an economic question, the result of supply and demand in the market. Economics is the study of how people choose to allocate their scarce resources. ${ }^{82}$ The price for each resource that contributes to the profit is determined by demand and supply. ${ }^{83}$ Capital and IP might be scarce resources 'creating value'. ${ }^{84}$ In addition to looking at this 'supply side' of profit generation, the demand side (revenue) should be considered. ${ }^{85}$

By maintaining the traditional transfer pricing question of which economic activities create which profits, the OECD continues supporting substantial profit attribution to mobile production factors such as capital and IP, which can relatively easily be shifted legally to tax friendly locations. If the OECD wanted to tax profits based on sales and employees, it should step away from the traditional transfer pricing question of which economic activities create which profits, and instead impose a tax based on the factors sales and employees.

\subsection{Corporation Tax Is among the Most Distorting Taxes}

At the time that MNEs paid low taxes in the countries where their products were sold (for high prices), citizens faced economic recession and governments faced high deficits after the economic crisis that started in $2008 .{ }^{86}$ In this light it is understandable that governments may be attracted to tax corporate profits. Voters generally perceive such taxes as being borne by companies or their wealthy owners and see it as a 'justified' way to increase tax revenues without hurting the public. With the public opinion on tax avoidance in mind, it was a small step for governments to try to increase tax revenue by combatting BEPS.

However, the tendency towards levying corporation tax might be unjustified. As noted by the Mirrlees review in 2011, 'perhaps the most important point to keep in mind when considering company taxation is that it is not meaningful to think about the effects of taxes on companies separately from the effects of those taxes on the individuals associated with companies' (such as the

80. J.R. Hines Jr., 'Income Misattribution under Formula Apportionment', 54 European Economic Review 108 (2010).

81. M.P. Devereux, 'Taxation of Outbound Direct Investment: Economic Principles and Tax Policy Considerations', 24 Oxford Review of Economic Policy 698 (2008), at 25.

82. W.J. Wessels, Economics (2000), at 2

83. Musgrave, above n. 7

84. M. Markham, The Transfer Pricing of Intangibles (2005).

85. See for a comparison Musgrave, above n. 7, at 228-46.

86. For in-depth analyses of developments in the build-up period to the launch of the BEPS initiative by G20 and OECD see R.S. Avi-Yonah, 'Globalization, Tax Competition, and the Fiscal Crisis of the Welfare State', 113 Harvard Law Review 1573 (2000), at 1573-1676. owners, employees, customers, etc.). ${ }^{87}$ Imposing a tax that is statutory borne by companies does not automatically mean that the economic burden of such tax is also borne by those companies (or its shareholders). ${ }^{88}$ Through product pricing and wages, it could very well be borne by the customers or employees of the company.

Who eventually bears the 'effective incidence' of a corporation tax is difficult, if not impossible, to predict. It depends on 'the form of the corporate tax, the nature of the economy in which it is levied, and the choices open to the firms on which it is imposed' ${ }^{89}$ But some direction can be given, it seems at least. Recent empirical studies have demonstrated that an increase of corporation tax is to a large extent borne by the workforce through lower wages. ${ }^{90}$

In addition, corporation taxes are considered to be among the most distorting taxes. ${ }^{91}$ Taken into account this observation and the expectation that corporation taxes are in the end to a large extent borne by the workforce, it could very well be that employees would be better off if their wages or expenses would be taxed directly. ${ }^{92}$

\subsection{The Responsibility of Paying a 'Fair Share'}

In international taxation, the responsibility to determine which country may tax which profits when MNEs do business in more than one country is laid in the hands of MNEs. This has been done by continuing with the arm's length principle (Article 9 of the OECD Model Convention). Any alternative would increase the risk of double taxation or would require an alternative allocation system. Apparently, early in the BEPS discussions the participating countries have not been able to agree on how to divide income from taxation on worldwide profits themselves in an alternative way, for example by treating an MNE as one taxpayer that pays taxes on its worldwide income in one country. ${ }^{93}$ This country then divides the tax income between all countries in which the MNE is active. Such a solution requires international tax coordination of an unprecedented level, and a willingness of countries to give up their sovereignty in

87. J. Mirrlees et al., 'Tax by Design' (2011), available at <www.ifs.org.uk/ publications/5353> (last visited 20 June 2017) at 408.

88. See W. Vermeend et al., Taxes and the Economy; a Survey on the Impact of Taxes on Growth, Employment, Investment, Consumption and the Environment (2008), at 41 and 156.

89. Ibid., at 409 .

90. W. Arulampalam, M. Devereux \& G. Maffini, 'The Direct Incidence of Corporate Income Taxes on Wages' (2012), 56 European Economic Review 6, at 1038-54

91. OECD, 2008, Taxation and Economic Growth.

92. J. Mirrlees et al., above n. 87 , at 411 .

93. Worth noting is that this meets the observations of the US state tax authorities close to a century ago: 'there is no right rule of apportionment $(\ldots)$ the only right rule (...) is a rule on which the several states can and will get together as a matter of comity'. See C.S. Lamb et al., 'Report of Committee on the Apportionment between States of Taxes on Mercantile and Manufacturing Business' (1922), 15 National Tax Association, 198-212, at 202. 


\begin{tabular}{llll}
\hline Orientation & Source & Considerations & Central question \\
\hline Egoism & Own interest & Profits & What helps me most? \\
\hline Legalism & Law and rules & Fines, court cases & What does the law require? \\
\hline Conformism & Expectations of others & Reputation, acceptation & What do other expect from? \\
\hline Ethical & Balanced interest & $\begin{array}{l}\text { Conscious and general } \\
\text { interest }\end{array}$ & What is best for all stakeholders? \\
\hline Altruism & Interest of others & Sacrifice & What helps others most?
\end{tabular}

taxation (like the CCCTB). ${ }^{94}$ More importantly, this requires countries to make a division of profits with which they all agree. Countries have not been able to come to such an agreement and made MNEs responsible to divide profits between countries. May it be expected from an MNE that it divides profits in such a way that all countries are 'happy' with their share? ${ }^{95}$

The responsibility to divide profits gives MNEs the freedom to arrange their transfer pricing in such a way that total taxation is lowest, while they still comply with local legislation in each country. The question arises whether - besides a legal obligation to pay tax - there is also a 'moral obligation' to pay tax if the law allows to reduce taxation to a minimum. In this regard, the observation of the US Judge Learned Hand is famous:

Anyone may arrange his affairs so that his taxes shall be as low as possible; he is not bound to choose that pattern which best pays the treasury. There is not even a patriotic duty to increase one's taxes. ${ }^{96}$ Over and over again the Courts have said that there is nothing sinister in so arranging affairs as to keep taxes as low as possible. Everyone does it, rich and poor alike and all do right, for nobody owes any public duty to pay more than the law demands: taxes are enforced exactions, not voluntary contributions. To demand more in the name of morals is mere cant. ${ }^{97}$

94. On 25 October 2016, as part of a broader package of corporate tax reforms (see European Commission, 'Corporate Tax Reform Package' (2016), available at <https://ec.europa.eu/taxation_customs/business/ company-tax/corporate-tax-reform-package_en_en> (last visited 20 June 2017)), the European Commission released proposals for a socalled CC(C)TB, relaunching its original CCCTB proposal of 16 March 2011 in two stages, essentially with a view to introducing unitary taxation and formulary apportionment in the internal market; see Proposal for a Council Directive on a Common Corporate Tax Base (CCTB) of 25 October 2016, 2016/0337; Proposal for a Council Directive on a Common Consolidated Corporate Tax Base (CCCTB) of 25 October 2016, 2016/0336; and see Proposal for a Council Directive on a Common Consolidated Corporate Tax Base (CСCTB) of 16 March 2011, 2011/0058.

95. The Commission proposals for introducing a СССТВ for instance have already met some fierce resistance by a number of EU Member States and some have raised formal objections against the proposals; see for an overview EUR, 'Procedure 2016/0336/CNNS' (2016), available at <http://eur-lex.europa.eu/legal-content/ENG/HIS/?uri=COM:2016: 683:FINforanoverview> (last visited 20 June 2017).

96. U.S. Court of Appeals for the Second Circuit, Helvering v. Gregory, 69 F.2d 809 (1934).

97. U.S. Court of Appeals for the Second Circuit, Commissioner of Internal Revenue v. Newman, 159 F.2d 848 (1947).
Following this conclusion, countries cannot rely on the moral duty of MNEs to pay more tax than required by law. In our view, MNEs may voluntarily pay more taxes than law requires, but may also take on a different attitude. The attitudes towards taxation can be distinguished as in the table above. ${ }^{98}$

In view of the observation of the US Judge Learned Hand stated above, ${ }^{99}$ MNEs may in our view choose any attitude with a minimum of legalism. In our observations as tax practitioners, we see a shift from legalism to conformism. Legalism and to a lesser extent conformism allow for tax optimisation. If countries do not want to run the risk that certain profits remain low taxed, they should divide the profits themselves. With the choice of making tax payers responsible for dividing profits, countries shifted the risk of double taxation to tax payers, but also the risk of double non-taxation. For the future of tax advisory, we see an important role for tax advisers to create awareness of the potential attitudes and to match the tax advice that is given to clients to the selected attitude. The role of tax advisory shifts from advising MNEs on the lowest possible effective tax rate to a broader advise including risks, risk appetite and public expectations.

\section{Conclusions}

Politics perceives taxation of MNEs as not aligned with the economic activity that produces their profits (i.e. not aligned with 'value creation'). In this perception, value creation is for the main part attributable to sales and to employees. But value creation is not necessarily attributable to sales and employees. Value creation is an economic question, the result of supply and demand in the market. In BEPS Actions 8-10, the OECD maintains the traditional transfer pricing question of which economic activities create which profits. Thereby, the OECD keeps the risk alive that substantial profits are attributable to mobile scarce production factors such as capital, which can relatively easily be shifted to tax friendly locations. If the OECD wanted to tax profits

98. Derived from VNO-NCW and MKB-Nederland, Leiderschap in ethiek, Inspiratie voor een baanbrekende ethiek voor bedrijven (2016), at 11, and further applied in the field of taxation by T. Bender, 'Tussen ethiek en wet: een derde weg', Weekblad Fiscaal Recht 20 (2017).

99. U.S. Court of Appeals for the Second Circuit, above n. 96. 
based on sales and employees, it should step away from the traditional transfer pricing question of which economic activities create which profits, and instead impose a tax based on factors that are less mobile (e.g. sales and employees). As the proposed solution is not fully aligned with the underlying intentions of politicians, many uncertainties arise.

How will this impact tax structuring and tax advisory? We expect the following consequences:

- Actions 8-10 combat existing tax planning opportunities for MNEs, but does so in a way that it creates more disputes with tax authorities, a shift of functions away from high tax countries, a diminishing value of the OECD Transfer Pricing Guidelines and new tax planning opportunities. As such, Actions 8-10 may not be the best way to reduce 'aggressive tax planning'.

- Tax planning will focus more on tax beneficial structures in which the business set-up runs parallel with the tax structure. We expect the use of empty cash boxes (e.g. intellectual property (IP) companies) to reduce, knowing that tax authorities will challenge such structures. The IP will be relocated to locations with the relevant substance to manage the IP, while the arm's length principle, notwithstanding the changes of Actions 8-10, is expected to leave sufficient opportunities to keep the tax benefits.

- Tax advisers need to take a more critical role towards positions taken by tax authorities and not automatically accept their positions as the 'truth'. Some tax authorities will be tempted to argue that more profits should be allocated to them provoked by the ambiguous guidance on how associated enterprises should price their transactions We fear that this will lead to more 'aggressive tax collection' by tax administrations.

- For the future of tax advisory, we see an important role for tax advisers to create awareness of the potential attitudes of clients towards tax structuring and to match the tax advice that is given with the selected attitude. The role of tax advisory shift from advising MNEs on the lowest possible effective tax rate to a broader advise including risks, risk appetite and public expectations.

- MNEs will avoid discussions with tax authorities by proactively claiming taxable presence in a country. In our observations as tax practitioners, from a tax perspective MNEs will prefer working with one legal entity with permanent establishments in each country where it formerly operated through a legal entity, even though there are business reasons to use separate entities. This reduces discussions about the presence of PEs of various legal entities, and reduces the taxable presence in each country to one legal entity.

- Action 13 will contribute to identify tax avoidance and aggressive tax planning, it will put more pressure to act in accordance with 'expectations' of tax authorities and to work with 'standard' structures, it will create a substantial administrative burden and more compliance work, and in our observations as tax prac- titioners, it will tempt MNEs to accept 'incorrect' audit adjustments to avoid having to deviate from a consistently applied transfer pricing system. 